\title{
The rarity of gastroliths in sauropod dinosaurs - a case study in the Late Jurassic Morrison Formation, western USA
}

\author{
O. Wings
}

Niedersächsisches Landesmuseum Hannover, Willy-Brandt-Allee 5, 30169 Hanover, Germany

Museum für Naturkunde Berlin, Invalidenstraße 43, 10115 Berlin, Germany

Correspondence to: O. Wings (dr.wings@gmail.com)

Received: 30 April 2014 - Revised: 3 August 2014 - Accepted: 5 August 2014 - Published: 6 October 2014

\begin{abstract}
Occurrences of suspected sauropod geogastroliths and "exoliths" (exotic clasts) are compared with authentic finds of stomach stones in the sauropods Diplodocus, Cedarosaurus, and Camarasaurus. Sedimentological and taphonomical evidence from classic sauropod dinosaur localities in the Late Jurassic Morrison Formation (Cleveland-Lloyd Dinosaur Quarry, Dry Mesa Dinosaur Quarry, Carnegie Quarry/Dinosaur National Monument, Howe Quarry, Como Bluff, and Bone Cabin Quarry) reveals very few sauropod finds with unambiguous gastroliths. The scarcity of clasts in the fine-grained sediments of most of the localities suggests that only a small number of sauropods possessed gastroliths. The occurrence of a hypothetical avian-style gastric mill in sauropods is not supported by taphonomical evidence. Exoliths that are abundant in the Early Cretaceous of the western USA are nearly absent in Late Jurassic sediments. Without an association with fossil bone, there is no convincing evidence that such clasts represent former gastroliths. It is more plausible that most exoliths have been transported in hyperclastic flows or that surface-collected stones are weathering relicts of former conglomerate layers.
\end{abstract}

\section{Introduction}

One of the most interesting topics of herbivorous dinosaur paleobiology is the digestion and nutrition of sauropods, the largest terrestrial vertebrates of all time (Sander et al., 2011). With notable exceptions, such as Bonitasaura (Apesteguía, 2004) or Nigersaurus (Sereno et al., 2007), sauropod dentitions possessed either pencil-shaped teeth restricted to the front of the snout (diplodocoids and titanosaurs) or spoon-shaped teeth with wear facets (basal sauropods and basal macronarians) (Upchurch and Barrett, 2000). Hence, sauropods lacked extensive mastication capabilities (Sander et al., 2011) and it was therefore assumed that all sauropods utilized geo-gastroliths (stomach stones) in an avian-style gastric mill (Bakker, 1986; Currie, 1997).

Stones have indeed been found with sauropod skeletons (see for example, Christiansen, 1996; Gillette, 1994; Sanders et al., 2001; Janensch, 1929a; Jennings and Hasiotis, 2006). However, given the abundance of articulated sauropod remains worldwide, the paucity of associated gastroliths is striking and raises the question of whether their absence can be explained by taphonomical processes alone. This resulted in opposing viewpoints regarding sauropod gastroliths: one group of authors mostly ignores finds (e.g., Calvo, 1994; Lucas, 2000), and another group firmly believes in the presence of gastroliths and a taphonomical bias (e.g., Christiansen, 1996). Furthermore, in the absence of evidence of gastrolith-aided trituration of foodstuffs in sauropods (Wings and Sander, 2007), the authenticity of sauropod gastroliths can be debated in general.

The aim of this study is to determine how common occurrences of sauropod gastroliths are in the fossil record. To address that problem, focus was placed on the occurrence of gastroliths in classic dinosaur localities of the Late Jurassic Morrison Formation, one of the richest dinosaur-bearing formations worldwide (e.g., Foster, 2003; Dodson et al., 1980a; Foster, 2007) representing a depositional paleoenvironment of semi-arid fluvio-lacustrine floodplains (Demko and Parrish, 1998; Turner and Peterson, 2004; Dodson et al., 1980b).

When discussing sauropod gastroliths, it is important to distinguish between genuine gastroliths and exotic clasts, socalled "exoliths" (Wings, 2004, 2007). Clasts found on the 
surface of dinosaur-bearing formations are frequently polished and have been suggested to represent the gastroliths of sauropods where all bone material has been destroyed (Bakker, 1986). They also have often been called "gastroliths" by other workers (Stokes, 1942, 1987) - an a priori assumption as there is no convincing evidence that these clasts actually represent former gastroliths. Hence, such clasts should be called exoliths (exotic rocks not in agreement with the hydrodynamic characteristics of the embedding sediment, e.g., pebbles in a fine-grained matrix, which may show a high polish and which potentially (but not necessarily) were former gastroliths; Wings, 2004, 2007).

\section{Methods}

The sedimentology and taphonomy of numerous sauropod localities was examined to seek potential associations of gastroliths and possible reasons for their absence. Fieldwork and first-hand observations were conducted at many classic sites in the North American Late Jurassic Morrison Formation, including the Carnegie Quarry in the Dinosaur National Monument, Cleveland-Lloyd Dinosaur Quarry, Como Bluff and Bone Cabin Quarry, Dry Mesa Dinosaur Quarry, Howe Quarry, and Howe Stephens Quarry (Fig. 1). These sites were complemented by studies of the field sites and the collection material of the Early Cretaceous gastrolith-bearing sauropod Cedarosaurus weiskopfae and the Late Jurassic gastrolith-bearing sauropod Diplodocus "Seismosaurus" longus (Fig. 1) as well as visits to Jurassic localities near Lourinhã in Portugal and the Chubut region of Argentina.

Fieldwork focused on comparative study of available sedimentary rocks, sauropod finds at these localities, their taphonomy, and prospecting for exotic stones in and around the quarries. The taphonomy of in situ sauropod bones at Dinosaur National Monument was checked regarding possible gastrolith loss. At all studied sites, the role of scavenging was taken into account, as a possible reason for the absence of gastroliths in sauropod skeletons.

Data for Tendaguru in Tanzania and the "Something Interesting Quarry" in Wyoming were collected from the literature. During visits to relevant museum collections (American Museum of Natural History, Utah State University Eastern Prehistoric Museum in Price, Denver Museum of Natural History, Museum für Naturkunde Berlin, New Mexico Museum of Natural History, Carnegie Museum of Natural History Pittsburgh, Staatliches Museum für Naturkunde Stuttgart, Sauriermuseum Aathal, Yale Peabody Museum), the available gastrolith material and general bone preservation of the localities were studied. When available, old field notes and publications about the quarries were inspected too.

Fossil vertebrate skeletons with gastroliths show that the stones are often preserved in the body cavity or at least in close association with the skeleton (Sanders et al., 2001; Darby and Ojakangas, 1980; Currie, 1981; Whittle and Ever-

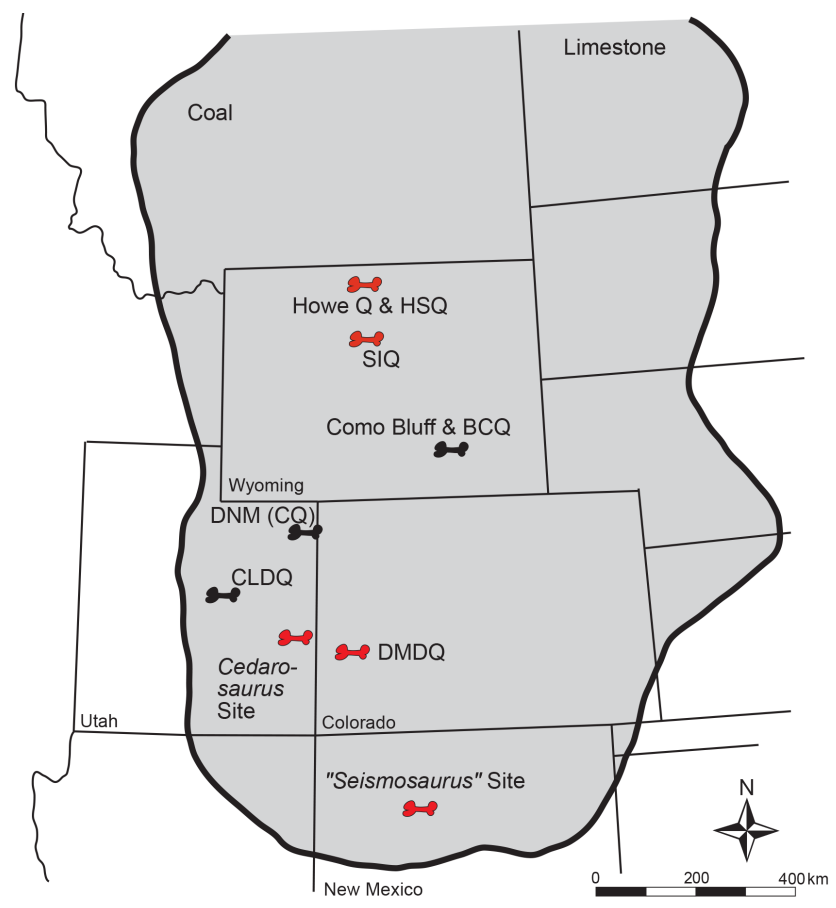

Figure 1. Studied dinosaur localities in the western USA. The surrounding line represents the extension of the Morrison Formation. Abbreviations: BCQ - Bone Cabin Quarry; CLDQ - ClevelandLloyd Dinosaur Quarry; DMDQ - Dry Mesa Dinosaur Quarry; DNM (CQ) - Dinosaur National Monument (Carnegie Quarry); Howe Q and HSQ - Howe Quarry and Howe Stephens Quarry; SIQ - "Something Interesting Quarry" (Camarasaurus). The red bones represent sites where gastroliths have been found in association with bones. Redrawn and modified from Dodson et al. (1980b).

hart, 2000; Wings, 2004). Hence, the null hypothesis is that if all sauropod dinosaurs required stomach stones for food processing, as suggested by several authors (e.g., Bakker, 1986; Currie, 1997), then many relatively complete skeletons should have associated gastroliths. Autochthonous and parautochthonous skeletons in fine-grained sediments are especially relevant for testing this hypothesis, and a special focus was given to localities which produced articulated or well-associated sauropod material. To set the framework and to understand the context between stratigraphy, sedimentology, taphonomy, taxonomy, and the appearance of gastroliths and exoliths, detailed descriptions of the localities were compiled.

\section{Results}

The localities are discussed in alphabetical order and the data are summarized in Table 1. 
Table 1. Summary of information for selected quarries. For references and discussion see text.

\begin{tabular}{|c|c|c|c|c|c|c|c|c|c|c|}
\hline Locality & Stratigraphy & $\begin{array}{l}\text { Depositional } \\
\text { environment }\end{array}$ & Sedimentology & Taphonomy & $\begin{array}{l}\text { Origin of } \\
\text { carcasses }\end{array}$ & $\begin{array}{l}\text { Amount of } \\
\text { material }\end{array}$ & $\begin{array}{l}\text { General } \\
\text { diversity }\end{array}$ & $\begin{array}{l}\text { Sauropod } \\
\text { diversity }\end{array}$ & $\begin{array}{l}\text { No. of sauro- } \\
\text { pod individu- } \\
\text { als }\end{array}$ & $\begin{array}{l}\text { No. of } \\
\text { clasts }\end{array}$ \\
\hline $\begin{array}{l}\text { Carnegie } \\
\text { Quarry, } \\
\text { Dinosaur } \\
\text { National } \\
\text { Monument }\end{array}$ & $\begin{array}{l}\text { Morrison Fm., } \\
\text { Brushy Basin } \\
\text { Member }\end{array}$ & River channels & $\begin{array}{l}\text { Coarse sand- } \\
\text { stone, in parts } \\
\text { conglomeratic }\end{array}$ & $\begin{array}{l}\text { Carcasses } \\
\text { washed } \\
\text { together; } \\
\text { articulated } \\
\text { skeletons are } \\
\text { abundant }\end{array}$ & $\begin{array}{l}\text { Allochthonous - } \\
\text { parautochthonous }\end{array}$ & $\begin{array}{l}\text { Some } 5000 \\
\text { bones, } 60-300 \\
\text { dinosaurs }\end{array}$ & High & 4 genera & $>20$ & 0 \\
\hline $\begin{array}{l}\text { Cleveland- } \\
\text { Lloyd } \\
\text { Dinosaur } \\
\text { Quarry }\end{array}$ & $\begin{array}{l}\text { Morrison Fm., } \\
\text { Brushy Basin } \\
\text { Member }\end{array}$ & $\begin{array}{l}\text { Water hole, } \\
\text { oxbow lake }\end{array}$ & Mudstone & Miring in mud & Autochthonous & $\begin{array}{l}10000 \text { disar- } \\
\text { ticulated bones } \\
\text { of at least } 70 \\
\text { individuals }\end{array}$ & Medium & $\begin{array}{l}3 \text { valid gen- } \\
\text { era, maximum } \\
6 \text { genera }\end{array}$ & 10 & $2 ?$ \\
\hline $\begin{array}{l}\text { Como } \\
\text { Bluff/Bone } \\
\text { Cabin Quarry }\end{array}$ & $\begin{array}{l}\text { Upper part of } \\
\text { the Morrison } \\
\text { Fm. }\end{array}$ & River channels & $\begin{array}{l}\text { Fine-grained } \\
\text { sandstones and } \\
\text { claystones }\end{array}$ & $\begin{array}{l}\text { Isolated skele- } \\
\text { tons and } \\
\text { articulated } \\
\text { skeletons } \\
\text { washed } \\
\text { together }\end{array}$ & $\begin{array}{l}\text { Allochthonous - } \\
\text { parautochthonous }\end{array}$ & $\begin{array}{l}\text { Thousands of } \\
\text { bones (only in } \\
\text { BCQ approx. } \\
69 \text { partial } \\
\text { skeletons) }\end{array}$ & High & 5 genera & $\begin{array}{l}\text { Como Bluff: } \\
\text { unknown; } \\
\text { BCQ: } 44\end{array}$ & $\begin{array}{l}\text { Como: } 0 \text {; } \\
\text { BCQ: } 0\end{array}$ \\
\hline $\begin{array}{l}\text { Dry Mesa } \\
\text { Quarry }\end{array}$ & $\begin{array}{l}\text { Morrison Fm., } \\
\text { Brushy Basin } \\
\text { Member }\end{array}$ & River channels & $\begin{array}{l}\text { Conglomeratic } \\
\text { sandstones }\end{array}$ & $\begin{array}{l}\text { Bones washed } \\
\text { together, } \\
\text { mainly } \\
\text { disarticulated } \\
\text { skeletal } \\
\text { elements }\end{array}$ & Allochthonous & $\begin{array}{l}\text { More than } \\
4000 \text { mainly } \\
\text { isolated skele- } \\
\text { tal elements }\end{array}$ & $\begin{array}{l}\text { Very high } \\
\text { (highest in the } \\
\text { Morrison Fm.) }\end{array}$ & 5 genera & $>20$ & $500-600$ \\
\hline Howe Quarry & $\begin{array}{l}\text { Morrison Fm. } \\
(145.7 \mathrm{Myr})\end{array}$ & $\begin{array}{l}\text { Water hole, } \\
\text { oxbow lake }\end{array}$ & $\begin{array}{l}\text { Siltstone, in } \\
\text { parts sandy }\end{array}$ & $\begin{array}{l}\text { Miring in } \\
\text { mud }\end{array}$ & Autochthonous & $\begin{array}{l}\text { More than } \\
4000 \text { bones } \\
\text { of at least } \\
25 \text { animals }\end{array}$ & Low & 3 genera & 25 & 64 \\
\hline $\begin{array}{l}\text { Howe } \\
\text { Stephens } \\
\text { Quarry }\end{array}$ & $\begin{array}{l}\text { Morrison Fm. } \\
(145.7 \mathrm{Myr})\end{array}$ & River channels & $\begin{array}{l}\text { Sandstone, } \\
\text { in parts } \\
\text { fine-grained }\end{array}$ & $\begin{array}{l}\text { Articulated } \\
\text { specimens }\end{array}$ & $\begin{array}{l}\text { Allochthonous - } \\
\text { parautochthonous }\end{array}$ & $\begin{array}{l}\text { At least } \\
10 \text { animals }\end{array}$ & High & 3 genera & 3 & 12 \\
\hline $\begin{array}{l}\text { Cedarosaurus } \\
\text { site }\end{array}$ & $\begin{array}{l}\text { Cedar Moun- } \\
\text { tain Fm., Yel- } \\
\text { low Cat Mem- } \\
\text { ber }\end{array}$ & $\begin{array}{l}\text { Floodplain } \\
\text { with low water } \\
\text { energy }\end{array}$ & Mudstone & $\begin{array}{l}\text { Isolated skele- } \\
\text { ton resting on } \\
\text { its belly }\end{array}$ & $\begin{array}{l}\text { Parautochthonous } \\
\text { - autochthonous }\end{array}$ & $\begin{array}{l}\text { Isolated } \\
\text { skeleton }\end{array}$ & Isolated find & 1 genus & 1 & 115 \\
\hline $\begin{array}{l}\text { Seismosaurus } \\
\text { site }\end{array}$ & $\begin{array}{l}\text { Morrison Fm., } \\
\text { Brushy Basin } \\
\text { Member }\end{array}$ & River channels & Sandstone & $\begin{array}{l}\text { Partially pre- } \\
\text { served isolated } \\
\text { skeleton }\end{array}$ & Parautochthonous & $\begin{array}{l}\text { Isolated } \\
\text { skeleton }\end{array}$ & Isolated find & 1 genus & 1 & $>240$ \\
\hline $\begin{array}{l}\text { "Something } \\
\text { Interesting } \\
\text { Quarry" } \\
\text { (Camarasaurus) }\end{array}$ & $\begin{array}{l}\text { Upper part of } \\
\text { the Morrison } \\
\text { Fm. }\end{array}$ & $\begin{array}{l}\text { Nearshore, } \\
\text { shallow, lacus- } \\
\text { trine setting }\end{array}$ & Mudstone & $\begin{array}{l}\text { Partially pre- } \\
\text { served isolated } \\
\text { skeleton, heav- } \\
\text { ily scavenged }\end{array}$ & Parautochthonous & $\begin{array}{l}\text { Isolated } \\
\text { skeleton }\end{array}$ & Isolated find & 1 genus & 1 & 14 \\
\hline
\end{tabular}

\subsection{Carnegie Quarry, Dinosaur National Monument (DNM)}

The quarry face at Dinosaur National Monument (DNM) Quarry, located near Vernal, Utah, provides an excellent opportunity to study several articulated sauropod finds in situ. Like many other dinosaur localities in the Morrison Formation, the DNM sediments were formed by fluvial channel deposits (e.g., Fiorillo, 1994; Lawton, 1977). The main bonebearing layer is composed of channels with sand and gritsized sediments (Lawton, 1977). Fiorillo (1994) characterized the sediment as a coarse, partially conglomeratic sandstone. In marginal areas, olive-green to violet siltstones are separated from the sandstones by an erosional surface, possibly representing riverbanks (Michelis, 2003).

Initially, it was estimated that the remains of approximately 60 dinosaurs were deposited during three or four depositional cycles (Dodson et al., 1980b; Fiorillo, 1994). After each cycle, a hiatus occurred with a drop in current energy and partial drying-out of the channel (Lawton, 1977).
Articulation of the skeletons varies greatly from isolated bones to complete articulated skeletons (Lawton, 1977; Dodson et al., 1980b). Lighter skeletal elements drifted further and some elongate bones were deposited parallel to the water currents (Lawton, 1977). A more recent study (Chure, 1997) even reported several hundred dinosaurs belonging to 10 genera. A number of reasonably complete skeletons of Camarasaurus, as well as those of Dryosaurus and Camptosaurus, were found among them. Evidence of scavenging can only be found on very few bones (Fiorillo, 1991).The bones show little weathering (stage 0 and 1 sensu Behrensmeyer (1978) and Fiorillo (1994); personal observations on DNM specimens at the Carnegie Museum).

Gastroliths and exoliths are completely absent from the Carnegie Quarry (personal observations, 2002; D. Chure, personal communication, 2002). No stones were found in association with several rather complete Camarasaurus skeletons (D. Chure, personal communication, 2002). The total absence of "anything that might be called gastroliths" from 
the immense bone accumulation at DNM was also noted by Stokes (1942).

Examination of the sediments around the bones in the quarry face did not reveal any potential gastroliths. Furthermore, fieldwork in Late Jurassic outcrops near DNM has not produced any clasts in the size commonly assumed for sauropod gastroliths ( $>3 \mathrm{~cm}$ in diameter; Wings, 2004; Wings and Sander, 2007). The largest siliceous clast discovered in the stratum which contained the richest bone deposits was approximately $2.5 \mathrm{~cm}$ in length. Yet, siliceous clasts of this size are exceptionally rare; the majority of the pebbles in the conglomeratic sandstones have diameters of less than $1 \mathrm{~cm}$. Larger $(\leq 10 \mathrm{~cm}$ in diameter) angular to rounded reworked mudstone and limestone clasts do occur, indicating a rather short transport distance (Michelis, 2003; Lawton, 1977).

\subsection{Cleveland-Lloyd Dinosaur Quarry (CLDQ)}

The Cleveland-Lloyd Dinosaur Quarry (CLDQ) is located in Emery County, Utah, and can be assigned to the lower part of the Brushy Basin Member of the Morrison Formation (Gates, 2005). Most bones were found in uniform calcareous smectitic mudstone layers (Richmond and Morris, 1996), representing an autochthonous assemblage in an ephemeral-pond setting (Gates, 2005). Personal examination of the outcrop revealed no signs of channel deposits or exoliths in the mudstone layers. The only pebble-rich stratum in the vicinity is the basal conglomerate of the Cedar Mountain Formation, which is stratigraphically higher than the quarry.

Seventy-five percent of the dinosaur remains from CLDQ belong to the theropod Allosaurus (Madsen, 1976). Sauropod remains are relatively rare: only two or three individuals of Camarasaurus, and some elements possibly belonging to more than one non-camarasaurid sauropod, were listed by Madsen (1976); Gates (2005) listed five Camarasaurus and one ?Barosaurus specimen. The theropod-dominated vertebrate assemblage of the CLDQ was taphonomically interpreted as a predator or scavenger trap (Dodson et al., 1980b). While drinking or hunting at a floodplain pond, the dinosaurs may have become entrapped in cohesive and adhesive mud (Richmond and Morris, 1996). The site was also considered a spring-fed pond or seep where the animals sank into the volcanic ash-rich mud before scavenging could take place (Bilbey, 1998, 1999). The newest taphonomical interpretation favors a drought-induced mass death assemblage (Gates, 2005).

During the removal of approximately 10000 bones from CLDQ, two exotic stones were noted by Stokes (1987) and described as "not typical gastroliths", possibly indicating a lack of polish. The repository of the two exoliths is unknown and they could not be examined.

\subsection{Como Bluff and Bone Cabin Quarry}

Due to their proximity, Como Bluff and the Bone Cabin Quarry (BCQ) are discussed together. Both areas are located in southern Wyoming, approximately $15 \mathrm{~km}$ apart. The sediments represent the upper part of the Morrison Formation (Schmude and Weege, 1996). Unfortunately, no general synopsis of the sedimentology and taphonomy of Como Bluff and BCQ has been published yet. Recent excavations by Western Paleontological Laboratories, Inc. in the BCQ area collected more sedimentological and taphonomical data (K. Cloward, personal communication, 2003).

The BCQ is situated on a hill of the Little Medicine Bow Anticline (Breithaupt, 1997a). The sediments are smectitic claystones, sandstones (occasionally chert-rich), and horizons of caliche, while non-swelling shales dominate the upper parts of the Morrison Formation (personal observations, 2002). The base of the overlying Early Cretaceous Cloverly Formation is marked by a prominent chert pebble conglomerate.

Como Bluff is a ca. $15 \mathrm{~km}$ long and $1.5 \mathrm{~km}$ wide breached anticline representing a complex fluviatile and lacustrine floodplain with a seasonal wet-dry cycle (Dodson et al., 1980b). Quarry 9 at Como Bluff, one of the richest microvertebrate localities in the Morrison Formation, represents a low-energy pond or swamp deposit (Carrano and VelezJuarbe, 2006). The depositional environment of BCQ can also be characterized as a braided river system with seasonal flooding as well as periods of drought or a dry season. The flooding is interpreted as non-catastrophic and more typical of high water runoff after storms and similar events (K. Cloward, personal communication, 2003).

Sauropod bones are not confined to a specific layer but can occur in neighboring channels. While the exact number of sauropod individuals found at Como Bluff is unclear, at least five sauropod taxa have been identified (Breithaupt, 1997a). A short synopsis of the rich vertebrate fauna of BCQ (including 44 sauropods) can be found in Breithaupt (1997b). The finds usually consist of rather complete individuals, often juveniles. Individuals are not scattered over large areas but are rather confined. The sediments in part of the BCQ West area were probably deposited by normal river flows. They contain numerous shed teeth from crocodiles, allosaurids, and sauropods together with heavily eroded and possibly redeposited bones. Many teeth were trapped behind and underneath larger bones (K. Cloward, personal communication, 2003). In other areas of BCQ, discoveries of skin impressions of a stegosaur, fragile skull parts of pterosaurs, and articulated crocodile osteoderms indicate very rapid burial with a subsequent dry period after the event and little disturbance (K. Cloward, personal communication, 2003).

Scavenging has been reported repeatedly from both sites. Matthew (1908) reported "scored and bitten off" bones of some herbivorous dinosaurs, including an incomplete ?Apatosaurus skeleton. Toothmarks on sauropod bones found in 
BCQ probably indicate late-stage scavenging (Hunt et al., 1994). Articulated portions of sauropod carcasses were exposed long enough to allow extensive alteration by theropods (Hunt et al., 1994).

Bakker (1986) reported associations of sauropod bones and carnosaur teeth from Como Bluff. During recent excavations in the BCQ area, little evidence of predation was recovered (K. Cloward, personal communication, 2003). Only one femur of a camarasaurid sauropod appeared to have been scavenged. No gastroliths were found in situ with articulated skeletons that have been recently excavated, and no exoliths were found in the channel lag material, or found isolated on the surface of relevant strata.

\subsection{Dry Mesa Dinosaur Quarry (DMDQ)}

The Dry Mesa Dinosaur Quarry (DMDQ) is located on the Uncompahgre Plateau, Mesa County, western Colorado, and belongs to the Brushy Basin Member of the Morrison Formation. These fluvial deposits consist of a broad sandstone channel incised into mudstones representing overbank deposits (Britt and Curtice, 1997) or, in an alternative interpretation, a lacustrine zeolite lithofacies (Richmond and Morris, 1998). The so-called "Christmas Tree Conglomerate" a colorful, pebble-rich, very coarse to medium-grained sandstone - is found stratigraphically $1 \mathrm{~m}$ below the quarry floor (Richmond and Morris, 1998). The depositional environment may have been a relatively straight bedload system (Richmond and Morris, 1998).

An immense accumulation of well-preserved bones was found at the base of crossbeds in the bottom of the river channel (Britt and Curtice, 1997). The bone accumulation possibly resulted from mass mortality of dinosaurs during a major drought and a subsequent cataclysmic flash flood and debris flow, with high flow velocities of around $200 \mathrm{~cm} \mathrm{~s}^{-1}$ (Richmond and Morris, 1998). Geological and taphonomical characteristics show that the transport distance of the bones prior to burial was short and that the bones represent an allochthonous accumulation (Richmond and Morris, 1998). In some cases, taphonomy suggests long-distance transport in fast-flowing water channels (K. Stadtman, personal communication, 2003).

The DMDQ has produced an exceptionally high number of bones (> 4000 elements) and has yielded the most diverse dinosaur fauna from any quarry in the Morrison Formation (Britt and Curtice, 1997). Most bones are isolated and cannot be assigned to specific individuals. Some articulated vertebral column segments and one partially articulated juvenile diplodocid were discovered. In two instances, posterior dorsal vertebrae, pelvic bones, and several caudal vertebrae were found in articulation (K. Stadtman, personal communication, 2003).

The minimum number of sauropod individuals found in the DMDQ is estimated to be more than 20. There are more than five valid sauropod genera represented, including
Diplodocus, Apatosaurus, Supersaurus, cf. Barosaurus, Camarasaurus, Brachiosaurus, and Haplocanthosaurus (Britt and Curtice, 1997). The genus Dystylosaurus is considered invalid (Lovelace et al., 2007).

During 30 years of excavation in the DMDQ, about 500600 exoliths have been found randomly in the bone deposit (K. Stadtman, personal communication, 2003). Part of this collection is retained at Brigham Young University, Provo, Utah. The bone deposit was somewhat bowl shaped, and was up to $1.5 \mathrm{~m}$ in depth in the center when collecting started. In the early years of excavation, exoliths were more common than in the thinned horizons excavated now. However, stones have never been found in relation to one of the few articulated skeletons or in a cluster. Pebbles found in situ in the sediments always exhibit a high polish and are mostly composed of chert. The most common exolith size is around $4 \mathrm{~cm}$, but the collections at Brigham Young University also include smaller sizes (K. Stadtman, personal communication, 2003).

Prospecting for exoliths in the area revealed no clasts either in the outcrop or on the surface of excavation dumps. The siliceous clasts in the conglomeratic parts of the sandstone channels are much smaller (maximum sizes around a few millimeters) than the exoliths in the collections. Only clay balls occurring occasionally in the sandstones can reach a few centimeters in size.

\subsection{Howe Quarry}

The Howe Quarry is situated in the Bighorn Basin near Greybull, Wyoming, and represents strata of the Morrison Formation with an estimated age of 145.7 Myr (Michelis, 2003).

The bones are found in shales, mudstones, and siltic sediments. The main bone-producing stratum is an olive-green, inhomogeneous mudstone of variable thickness (Michelis, 2003). All these sediments represent water flows of insufficient energy to transport heavy sauropod carcasses (Ayer, 2000; Michelis, 2003). The most plausible scenario is an autochthonous origin of the assemblage with the sauropods having been trapped in sticky sediments (Ayer, 2000; Michelis, 2003). Michelis (2003) proposed a selective process where physically weakened animals were mired in the mud of a water hole within a levee of a river.

Scavenging is indicated by abundant theropod ( $\mathrm{Al}$ losaurus) teeth and tracks, whereas direct evidence such as tooth marks is very rare (Michelis, 2003). Predators and scavengers were probably responsible for some disarticulation of the skeletons. Weathering of the bones prior to burial was very limited (weathering stages 0 or 1 ; Behrensmeyer, 1978), showing fast burial or mummification (Michelis, 2003). The weathering period before burial is estimated at no more than 4 years, but was usually much less (Michelis, 2003). Some 2400 bones of at least 25 partial sauropod skeletons have been found, with the genus Barosaurus dominating the fauna. Bird (1985) reported 64 gastroliths, found as a single cluster 


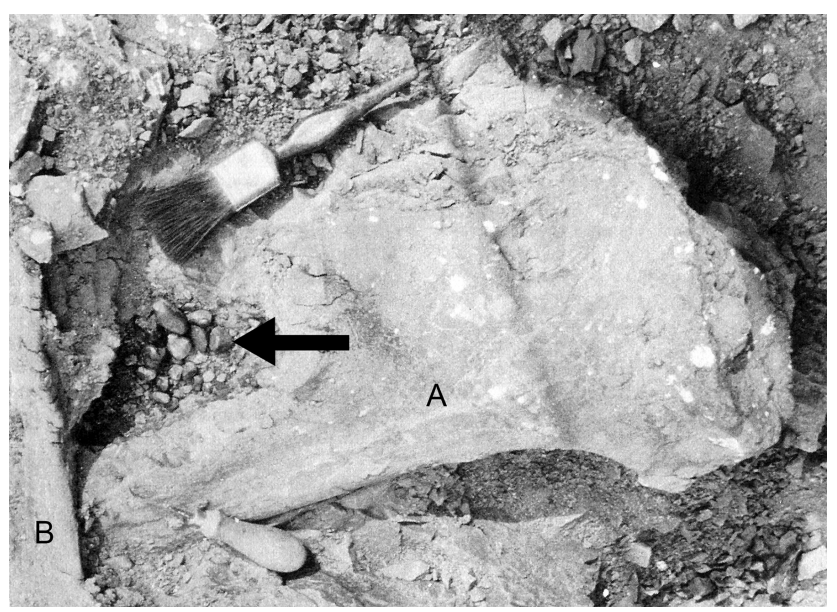

Figure 2. Photograph of gastroliths found at Howe Quarry. Next to a Barosaurus pubis (a) and an elongated bone (b), probably an abdominal rib, the cluster of 64 stones is visible. Modified from Bird (1985).

in the abdominal area of a Barosaurus skeleton (Figs. 2, 3). These stones were sent to the American Museum of Natural History in New York, but could not be located during a recent visit to the collections (I. Michelis, personal communication, 2000). Michelis (2003) reported at least 15 exoliths found in situ during new excavations in the Howe Quarry in 1990 and 1991. Another interesting specimen is a single quartz pebble with a size of approximately $2 \mathrm{~cm}$ that was found embedded in a carbonized patch in the sandstone matrix (Fig. 4). The carbonized material may represent former herbaceous stomach contents. All stones retrieved during the new excavations are stored in the Sauriermuseum Aathal in Switzerland. During field work by the author in 2002, exotic clasts were found only on the surface in the vicinity of the quarry. An examination of the quarry walls revealed no appropriate clasts in situ.

\subsection{Howe Stephens Quarry}

Several other dinosaur sites exist in the vicinity of the Howe Quarry. These sites, collectively named Howe Stephens Quarry (HSQ), are approximately $450 \mathrm{~m}$ away from the original Howe Quarry and are stratigraphically higher than the latter. The HSQ represents a different taphonomy to the Howe Quarry. Channel sandstones are commonly found, often containing plant debris. The site is interpreted as a fluvial deposit formed during a catastrophic flood that may have transported the carcasses for some distance before their final deposition (Ayer, 2000). Carcasses were covered rapidly by river sediments (Ayer, 2000).

The HSQ has also yielded an enormous concentration of articulated skeletons: at least 10 different dinosaur specimens (Ayer, 2000). Two relatively complete articulated sauropods were found without associated gastroliths (H. J. Siber, per- sonal communication, 2001). Another solitary sauropod skeleton was found in fine-grained crevasse splay sediments of HSQ "A-Pit" (Michelis, 2003), indicating a very low transport velocity.

In the sediments at the excavation sites, only about a dozen exoliths and gastroliths have been recovered, preserved in the Sauriermuseum Aathal (Ayer, 2000). Among them is the $\mathrm{Al}$ losaurus specimen "Big Al Two", which has probable stomach contents, including a relatively large gastrolith, preserved (Ayer, 2000). In contrast to the rarity of exoliths in situ, hundreds of exoliths can be found on the surface in the vicinity of the two quarries (Ayer, 2000; personal observation, 2002). However, these probably result from long-term weathering of conglomerates in the uppermost Morrison Formation and, especially, the Cloverly Formation (H. J. Siber, personal communication, 2002) or may represent weathered remains of glacial deposits.

\subsection{Additional sites}

Six additional sites and areas will be discussed briefly for supplementary information on authentic sauropod gastrolith finds and sauropod lagerstätten of similar depositional environments and age. Three important gastroliths-bearing sauropod sites in the western USA comprise the Cedarosaurus site, Seismosaurus site, and a Camarasaurus site. Together with three studied regions rich in Jurassic sauropod fossils (Lourinhã in Portugal, Chubut province in Argentina, and Tendaguru in Tanzania), they provide adequate verification for the occurrence of sauropod gastroliths.

\subsubsection{Cedarosaurus site}

A set of 115 clasts with a total mass of $7 \mathrm{~kg}$ and a total volume of $2703 \mathrm{~cm}^{3}$ was associated with the holotype skeleton of the brachiosaurid Cedarosaurus weiskopfae in the Yellow Cat Member of the Cedar Mountain Formation (Early Cretaceous) of eastern Utah (Sanders et al., 2001).

The embedding sediment was a maroon mudstone lacking inclusions and lenses of other materials, indicating a lowenergy floodplain environment. The gastroliths are composed of cherts, sandstones, siltstones, and quartzites. Many stones show a metallic (probably haematite) coating. The skeletal position indicates that the carcass came to rest in an upright position with the gastroliths preserved in situ (Sanders et al., 2001). All but three of the stones were found in a cluster covering an area of approximately $0.5 \mathrm{~m} \times 0.5 \mathrm{~m} \times 0.25 \mathrm{~m}$ (Fig. 5). The gastroliths are stored in the Denver Museum of Natural History.

\subsubsection{Seismosaurus site}

This locality (Morrison Formation, Brushy Basin Member) near San Ysidro, New Mexico, has exemplary importance as an association of sauropod skeletal material with possible gastroliths. More than 240 stones were found in 


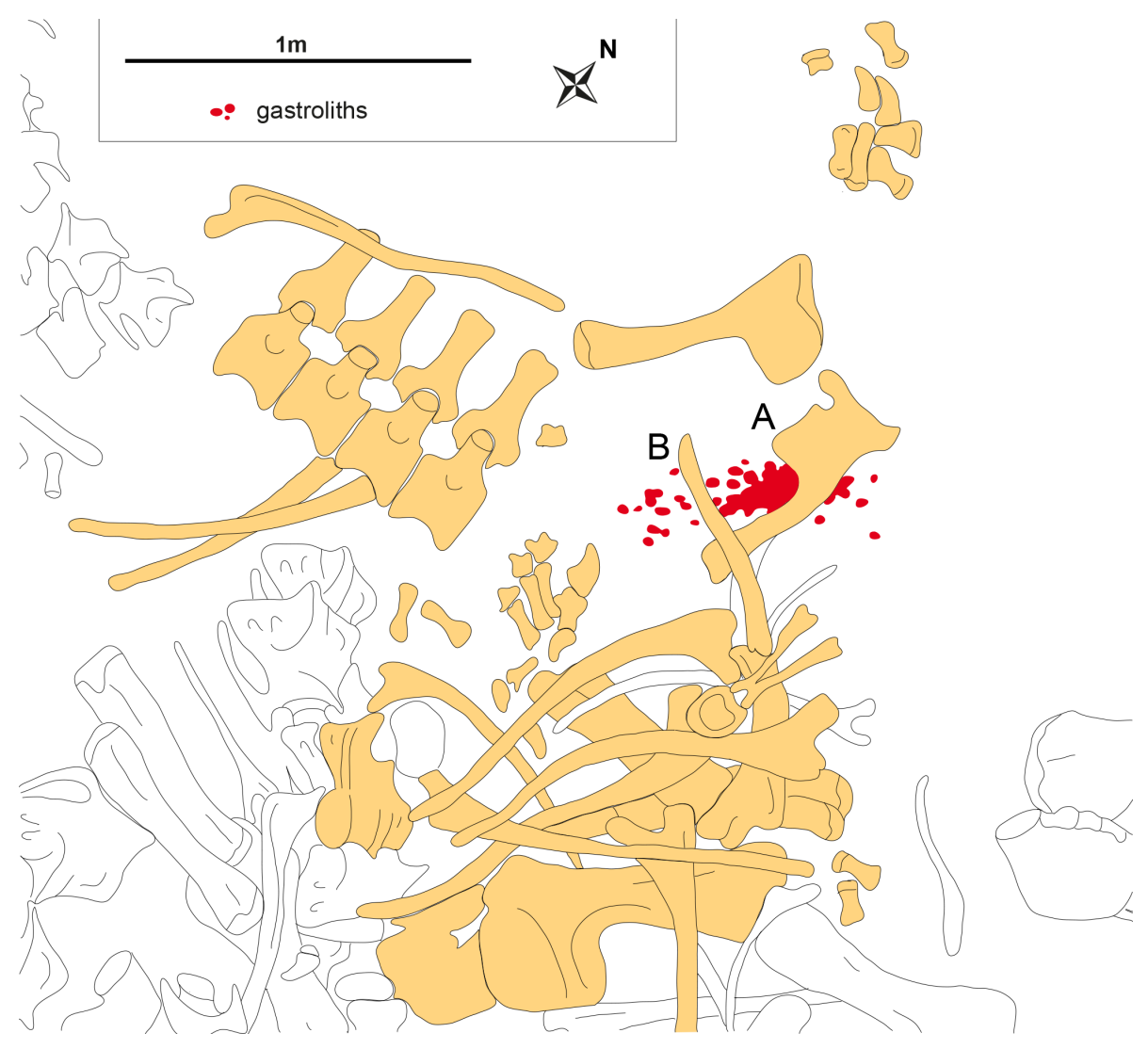

Figure 3. Section of R. T. Bird's Howe Quarry map showing the Barosaurus bones (yellow; A - pubis; B - abdominal rib?) as well as the gastroliths seen in the photograph in Fig. 2. The bones of the Barosaurus individual were partially articulated. Redrawn and modified from Rice and Bierwert (1935) and Michelis (2003).

direct association with the semi-articulated holotype skeleton of Diplodocus "Seismosaurus" hallorum (Lucas et al., 2006) and interpreted as gastroliths (Gillette, 1994). Phylogenetic analysis revealed that this specimen is likely a large Diplodocus longus (Lovelace et al., 2007).

The supposed gastroliths from this locality were well documented and used in follow-up studies (e.g., Manley, 1993), but the interpretation of the stones as gastroliths was questioned by Lucas (2000), who inferred them as streamdeposited cobbles in a channel lag deposit. Nevertheless, a reinvestigation of the sedimentological and taphonomical situation indicates that a gastrolith interpretation is the most parsimonious explanation for the clasts (Fig. 6). Two clusters were identified and some clasts were found within the ribcage in contact with ribs and vertebrae: a few gastroliths close to the ribcage were "crudely aligned and in serial contact, as though held in place by soft tissue before burial" (Gillette, 1992). All gastroliths are composed of chert and quartzite; the embedding matrix is a fluvial sandstone with a medium to coarse grain size (Gillette, 1991). Except for the gastroliths, no clasts or gravel occurred in the section containing the fossil bones (personal observations, 2002). The bones and gastroliths of Diplodocus "Seismosaurus" longus are curated in the New Mexico Museum of Natural History (NMMNH 3690) in Albuquerque.

\subsection{3 "Something Interesting Quarry" (Camarasaurus)}

The so-called Something Interesting (SI) Quarry is located near Thermopolis, in the Bighorn Basin in north-central Wyoming (Jennings and Hasiotis, 2006). The exposed upper part of the Morrison Formation has preserved two distinct sauropod bone assemblages with 101 shed theropod teeth. The lower assemblage is embedded in a clay-rich mudstone representing a shallow-water, palustrine-lacustrine setting. It yielded at least $40 \%$ of the bones of a juvenile Camarasaurus (Fig. 7). Abundant allosaurid teeth as well as toothmarks indicate scavenging (Jennings and Hasiotis, 2006). The scavenger activity was centered in the anal and gastrointestinal region of the sauropod, near which 14 polished quartz clasts (diameter: 1-13 cm), interpreted as gastroliths, were found too (Jennings and Hasiotis, 2006). Eleven of these gastroliths were restricted to $0.025 \mathrm{~m}^{3}$ of the clay-rich mudstone matrix between caudal vertebrae and broken pelvic bones (Jennings and Hasiotis, 2006). 


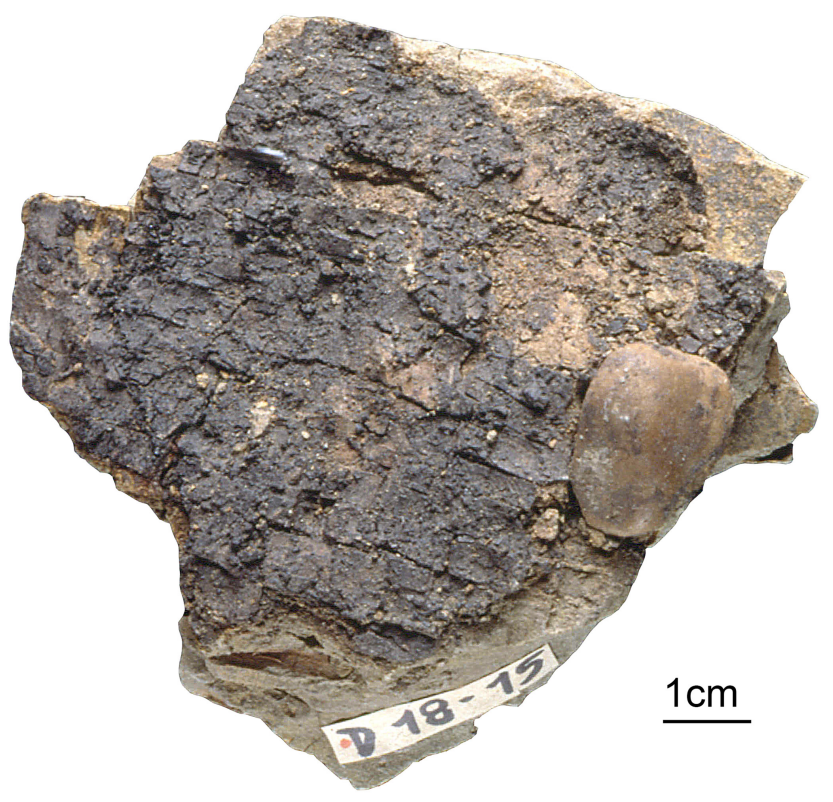

Figure 4. Carbonized material with a single gastrolith from Howe Quarry. The presence of plant matter surrounding the clast is interpreted as evidence of former stomach contents. This is specimen number D18-15 in the Sauriermuseum Aathal.

\subsubsection{Lourinhã, Portugal}

Lourinhã is situated in the Lusitanian Basin of western Portugal. The coastal exposures of distal alluvial fan sediments yield many vertebrate fossils, including more than 70 individuals from 7 sauropod species (Antunes and Mateus, 2003; O. Mateus, personal communication, 2003). The general geological setting and details of the facies types are rather similar to the Morrison Formation (Hill, 1989). At least three sauropods had associated gastroliths (O. Mateus, personal communication, 2003), including two of the best examples worldwide: almost 100 stones were found in close association with vertebrae of each of the holotypes of Dinheirosaurus lourinhanensis (Bonaparte and Mateus, 1999) and Lourinhasaurus alenquerensis (Dantas et al., 1998). The material is now stored in the Museu da Lourinhã, Portugal.

Fieldwork in 2000 revealed similar depositional settings to the North American Morrison Formation: exoliths are present, but are exceptionally rare. During 10 days of field work, only two isolated clasts were found in situ. No bone material was found in the vicinity of these stones.

\subsubsection{Chubut, Argentina}

The predominantly lacustrine Middle Jurassic Cañadón Asfalto Formation (Novas, 2009) in Chubut province, Argentina, is mostly composed of fine-grained mudstones; but bones have also be found in conglomerates or coarse sandstone layers (O. Rauhut, personal communication, 2007). This formation has produced at least 12 partial sauropod skeletons (O. Rauhut, personal communication, 2003). The overlying Late Jurassic Cañadón Calcáreo Formation, mainly composed of fluviatile sandstones, has produced an additional four associated sauropod skeletons (O. Rauhut, personal communication, 2003). No gastroliths were discovered with any of these skeletons, including Brachytrachelopan, where all ribs have been found in articulation (Rauhut et al., 2005). No exoliths were found during 3 weeks of prospecting (Wings, personal observations, 2001).

\subsubsection{Tendaguru, Tanzania}

The Late Jurassic beds of Tendaguru in Tanzania consist of three horizons of terrestrial marls alternating with marine sandstones (Maier, 1997; Janensch, 1929a; Aberhan et al., 2002). The sauropod genera Giraffatitan, Tornieria ("Barosaurus"), Australodocus, Dicraeosaurus, Janenschia, and Tendaguria (Janensch, 1929b; Maier, 1997; Bonaparte et al., 2000; Weishampel et al., 2004; Remes, 2006) were found in stages of disarticulation ranging from incomplete skeletons to solitary bones. Indications for carcass decay and postmortem transport are common (Heinrich, 1999). The minimum number of sauropods is given as 23 by Heinrich (1999), but could be above 50 (M. Sander, personal communication, 2003). Janensch (1929a, 1927) reported several associated gastroliths from a Tornieria ("Barosaurus") and a Dicraeosaurus specimen. During several years of intensive prospecting and excavation in the region, a total of 13 clasts were reported (Janensch, 1929a). Some of these clasts, which are curated at the Museum für Naturkunde Berlin, can be considered exoliths. In 1925, the British excavation leader at Tendaguru, F. W. H. Migeod, reported an accumulation of quartz pebbles associated with an unidentified partial dinosaur skeleton and interpreted this accumulation as a fluviatile deposit (Maier, 2003). It is possible that these clasts represented the best evidence of gastroliths in all African sauropods, but, because they were neither collected nor studied, gastroliths must be considered exceptionally rare in the Tendaguru region.

\section{Discussion}

Among the abovementioned North American material, there is conclusive evidence (fine-grained matrix without similar clasts, direct association with bone, clasts deposited as clusters) for genuine gastroliths in only four individuals: one Diplodocus longus, the type specimen of Cedarosaurus, one Camarasaurus, and one Barosaurus. Even though 600 isolated stones were found in the DMDQ, allometric comparison with birds has shown that this might have been just enough to support the gastroliths-aided trituration of foodstuffs the gizzard (i.e., an avian-style gastric mill) in a single medium-sized sauropod (Wings, 2004; Wings and Sander, 2007). While the presented data prove the irregular presence 


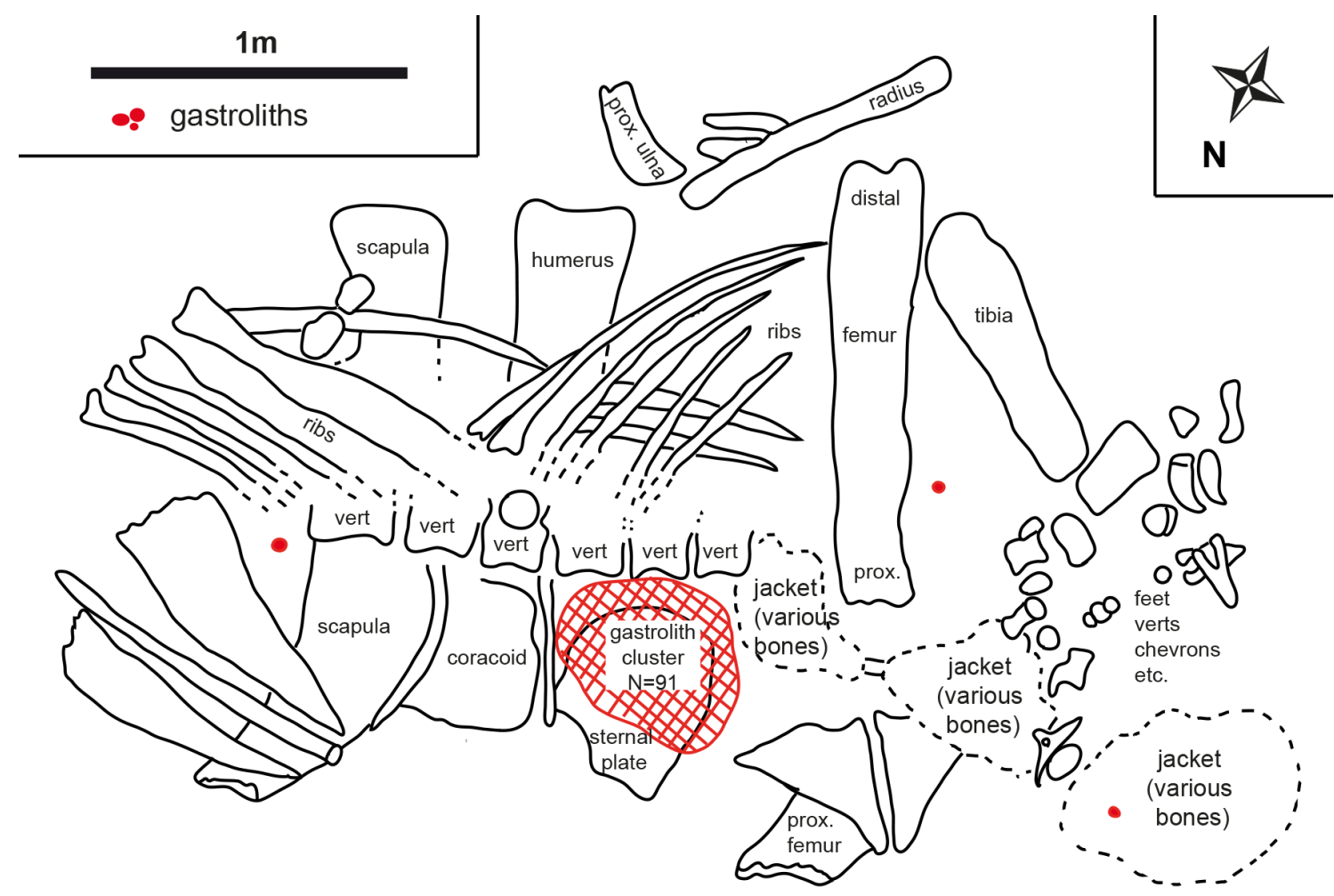

Figure 5. Cedarosaurus site field sketch, in which the gastrolith cluster is clearly visible. Three isolated gastroliths were dispersed throughout the skeleton. Redrawn and modified from Sanders et al. (2001).

of gastroliths in at least some sauropod taxa, the overall extremely rare occurrence of sauropod gastroliths is evident. These observations raise the following question: is the absence of gastroliths an artifact of special sedimentological and taphonomical circumstances? While general taphonomical processes leading to a separation of skeletal remains and gastroliths are discussed elsewhere (Wings, 2003, 2004), several plausible reasons for gastrolith absence in the majority of sauropod finds can be proposed, as in the following subsections.

\subsection{Material not recognized, recorded, or collected}

The absence of gastroliths from historic excavations could be the result of excavation crews simply not recognizing or collecting them. However, this is unlikely, as the first discussion of gastroliths in sauropods (Brown, 1907; Wieland, 1906; Cannon, 1906) had already been published when the Carnegie Quarry at DNM was discovered in 1909.

The absence of gastroliths associated with the dinosaur skeletons found at Como Bluff and CLDQ cannot be absolutely confirmed, because poor field notes do not allow detailed investigation. Yet, at CLDQ it is not plausible that the absence of gastroliths is a consequence of collection bias, since William M. L. Stokes, one of the excavation managers of the initial excavations, was very interested in gastroliths (e.g., Stokes, 1942, 1987).
It appears unlikely that clusters of pebbles and stones associated with articulated sauropod skeletons were not reported by early researchers. Moa remains associated with gastroliths were commonly reported at the end of the 19th century (e.g., Chapman, 1884; Hamilton, 1891). Also in the 19th century, clusters of clasts in fine-grained sediments were recognized as important exotic rocks, even if not hypothesized as possible gastroliths (Jukes-Browne and Hill, 1887). Therefore, it is likely that large clusters of exotic clasts (which would be expected if the clasts had a gastric function in dinosaurs) associated with dinosaur bones would have been noted by early researchers. The rarity of gastroliths with sauropod remains is furthermore encountered in recent excavations, suggesting that gastrolith density during early excavations was indeed low, as indicated by the collected material.

Perhaps gastroliths were overlooked because of unusual grain sizes. For example, the only possible gastrolith material in the DNM quarry would have been the conglomeratic sandstones with clasts in sizes $<25 \mathrm{~mm}$. But while pebbles of this grain size are used as gastroliths in many large bird species, their exclusive use as gastroliths in the large dinosaurs found at DNM is highly unlikely, since there is generally a correlation between animal size and gastroliths size in living animals (Gionfriddo and Best, 1999; Wings, 2004).

The rarity of exoliths found during fieldwork at the sauropod localities cannot be due to extensive collecting by 

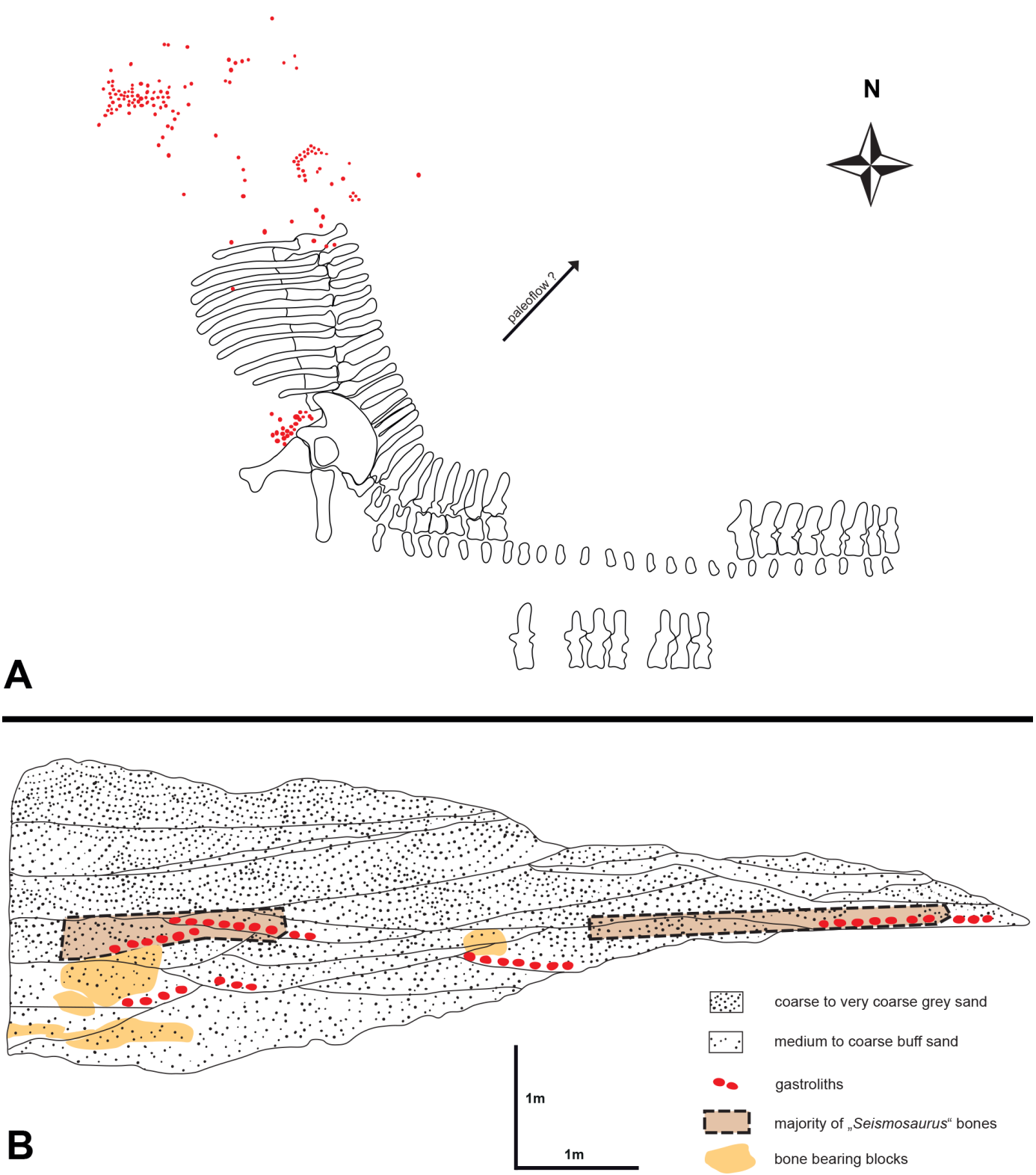

Figure 6. Distribution of bones and stones at the Diplodocus "Seismosaurus" longus locality (a) and cross section of the quarry (b). Note that bone-bearing blocks occurred below the first pebble lag and that there are two concentrations of gastroliths. A defined cluster was found in the pelvic area, whereas the majority of the stones were dispersed in the area north of the bone material. Redrawn and modified from Lucas (2000), and including information from Gillette (1994) (in a) and Schwartz and Manley (1992) (in b).

geologists and laymen (as suggested by Minor (1937) for the area around Rigg's Dinosaur Hill, Morrison Formation, near Fruita, Colorado) as early publications report that the Morrison Formation generally has few exoliths (Stokes, 1942). Stokes (1987) noted that, at DNM and CLDQ, "gastroliths" (exoliths) are abundant in the overlying Early Cretaceous Cedar Mountain Formation. It is plausible that exoliths found on the surface are weathering relicts from former conglomerates. The abundance of surface clasts in the Howe Quarry area can also be explained by glacial input.

\subsection{Loss under stress or during death}

The loss of gastroliths under stress or during prolonged death throes has been suggested (Janensch, 1929a; e.g., Gillette, 1994) to explain the rarity of associations of sauropod skeletons and gastroliths. However, the loss of all stones is not plausible. In no extant gastroliths-bearing species has such behavior ever been recorded. Furthermore, although this hypothesis could explain the absence of gastroliths in a few individuals, it would not apply to the majority of sauropods, 


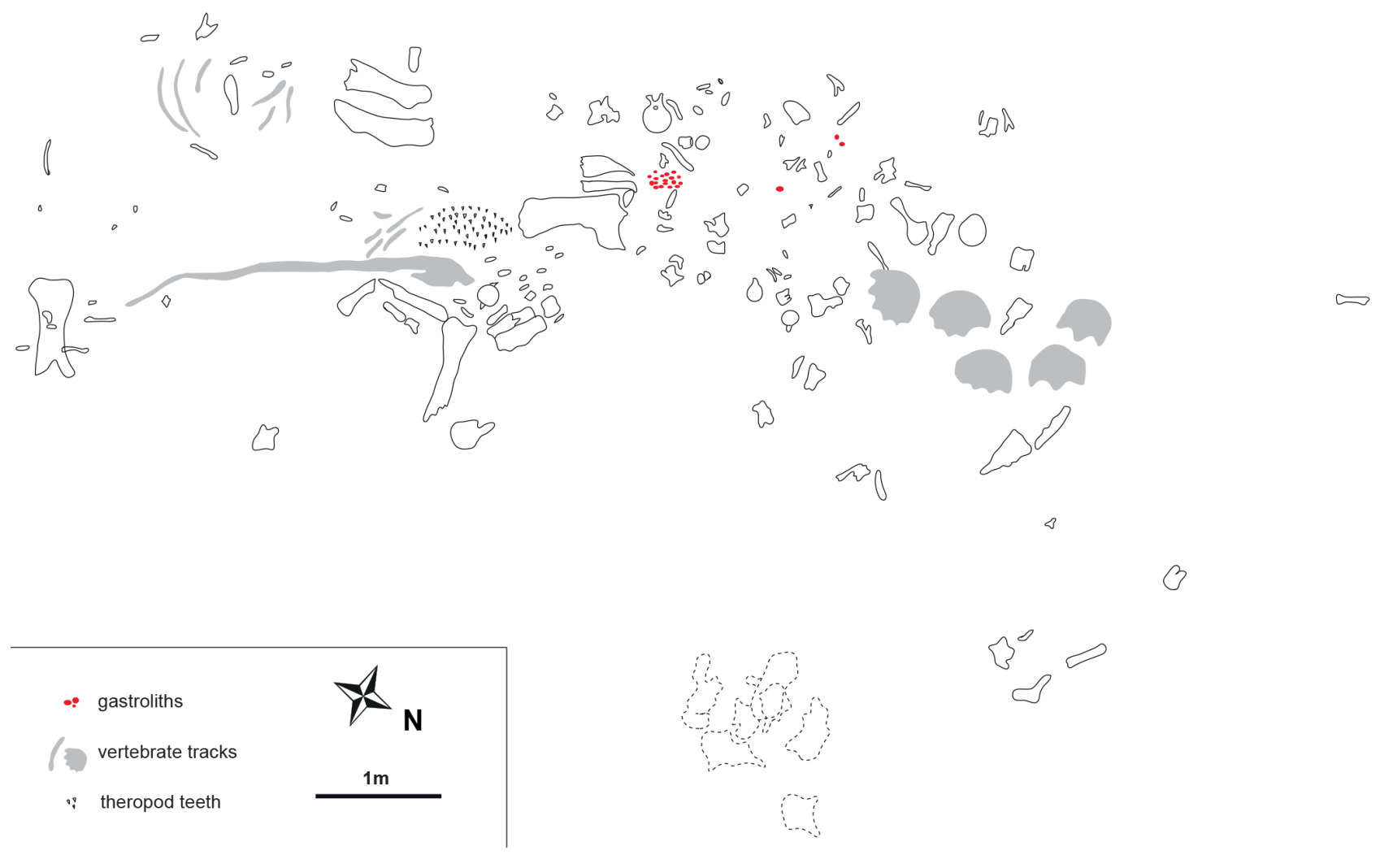

Figure 7. Plan-view map of the SI Quarry showing a scavenged juvenile Camarasaurus with vertebrate tracks, abundant theropod teeth, and gastroliths. Redrawn and modified from Jennings and Hasiotis (2006).

especially to animals in autochthonous settings or those whose rapid deaths are attributed to catastrophic events.

\subsubsection{Postmortem removal by scavengers}

Signs of scavenging (e.g., Como Bluff and the SI Quarry) suggest that gastroliths might have been transported and dislocated by scavengers. These gastroliths should have been deposited near the sauropod carcasses (as seen in the SI Quarry) or were swallowed by carnivores with carcass flesh. However, exoliths are not specifically abundant near sauropod fossils, and the absence of gastrolith clusters in carnivorous theropod skeletons, with the exception of the holotype of Lourinhanosaurus (Mateus, 1998), as well as in predatorrich dinosaur sites such as the CLDQ makes the complete removal of sets of gastroliths by scavengers implausible.

\subsubsection{Postmortem removal by sedimentological processes}

The release of gastroliths from carcasses can be a fast process (Wings, 2003), and transport processes in aquatic environments could potentially separate gastroliths from an otherwise complete carcass. However, transport processes can be completely ruled out when dealing with autochthonous skeletons in low-energy environments. Most transport pro- cesses would also affect fragile bones, not just gastroliths, and should be visible in the taphonomical record. Prolonged or highly energetic transport of carcasses would be indicated by poorly preserved bones. Such poorly preserved bones from classic Late Jurassic dinosaur localities, such as DNM, cannot be found in the relevant collections (personal observations, 2003). However, the overall excellent preservation of bones in the collections may result from a collection bias, as poorly preserved bones were probably not collected during the first excavations. For DNM for instance, the maximum time period for the formation of the bone bed was calculated as 19 years (Fiorillo, 1994). During that time, the bones could have been transported to the bone bed from several sources, such as river banks, reworked river channels upstream, or locally reworked sediments (Michelis, 2003). In all cases, if the skeletons had decayed or were scavenged before their final transport, a loss of the gut contents is probable. However, exceptionally complete skeletons, such as the Camarasaurus with preserved skull at DNM, indicate a very short transportation, and the complete burial of such carcasses with all stomach contents in place is plausible.

The gastrolith record at Howe Quarry (one cluster of 64 stones belonged to a single specimen; beside that, only 15 stones were associated with skeletal remains of 24 autochthonous individuals) raises the question of whether 
gastroliths might have been removed from the site. During the flood events that entombed the carcasses at Howe Quarry, the soft tissues would have decayed, therefore preventing gizzards from floating. Complete mummification of the gut contents and later fluviatile transport of the gastroliths is not likely. Although the mummified skin found at Howe Quarry permits such a scenario, complete mummified carcasses were not found (Michelis, 2003). Even if the gizzards were mummified, the combined weight of the gastrolith cluster would have made water transport difficult. Another reason why gastroliths should be present at Howe Quarry is that large bones are embedded vertically in the mudstones. During burial, these bones would have prevented any nearby items, including small bones, from being carried away (Michelis, 2003). Gastroliths should therefore also have been trapped between these bones.

While the total absence of gastroliths at DNM and at Como Bluff/BCQ could be a result of rare fluvial sedimentological processes (e.g., short periods of high-energy currents), the absence of suitable clasts at CLDQ, an autochthonous site, is an indication that gastroliths were not present in all sauropods.

\subsubsection{Postmortem removal by diagenetic processes}

Selective diagenetic dissolution (e.g., by $\mathrm{pH}$ changes in the groundwater) of gastroliths is very unlikely. Most gastroliths are composed of quartz, a highly resistant rock type that also commonly forms the embedding matrix (sandstones, siltstones, and mudstones) of the fossils.

\subsubsection{Postmortem removal by other sauropods}

The fine-grained sediments of the Morrison Formation indicate that stones suitable for use as gastroliths were rare in this habitat. Therefore, a speculative hypothetical scenario can be developed, where gastroliths have been utilized again and again by successive generations of sauropods until they were too small to be of use in the putative gastric mill. In situations where a carcass was exposed to weathering for several years, there might have been numerous opportunities for the stones to be picked up by other sauropods.

Anyhow, several arguments speak against this scenario. If sauropods migrated over extended distances (Paul, 1997), they could easily fulfill their demand for clasts in suitable sediments. The abrasion of resistant quartz clasts is relatively low in bird gizzards, and the stones survive several months in the stomach as shown in experiments on ostriches (Wings and Sander, 2007). If the stones had a similar function in sauropods, the animals would have survived several months without the need to replenish the stones.

Furthermore, such behavior has not been reported from any extant species in the wild. Observations on free-ranging farm ostriches, which had unlimited access to pebbles in their habitat, have shown that the birds do not accept gas- troliths from the stomach contents of slaughtered ostriches for several weeks (R. Schuhmacher, personal communication, 2003). On the other hand, preliminary research conducted by the author on 10-day-old ostrich chicks which had no former access to grit shows that the chicks accept former ostrich gastroliths if the stones are clean. Consequently, sauropods may have accepted former gastroliths as their own gastroliths if the stones were exposed for several months or years and if there was a limited sedimentary supply of stones. Nevertheless, this "reuse hypothesis" cannot explain the absence of stones in articulated and quickly buried skeletons.

\subsection{Genuine absence of gastroliths}

After eliminating other explanations, the genuine absence of gastroliths is the most parsimonious interpretation for the majority of the sauropods from the investigated sites. Furthermore, isolated gastroliths might not have been derived from sauropod carcasses but from other vertebrate clades. For example, while the sedimentological situation at DMDQ suggests that gastroliths are the most plausible reason for the isolated clasts in the sandstones, their assignment to a specific vertebrate group is uncertain. Beside dinosaur remains, many other vertebrate fossils are found in the DMDQ, including a crocodilian (Britt and Curtice, 1997). Since crocodilians regularly possess gastroliths (e.g., Cott, 1961; Whittle and Everhart, 2000; Wings, 2007) and fossil crocodilians are often found with gastroliths in situ (Wings, 2004), the isolated clasts could also derive from this clade.

\section{Conclusions}

The taphonomy of complete articulated and/or autochthonous sauropod skeletons in low-energy sediments allows the conclusion that only very few sauropods possessed gastroliths. Furthermore, most of these individuals possessed very small amounts of gastroliths. An estimate of the number of sauropod individuals with associated gastroliths shows that at most they comprise $2-4 \%$ of all sauropods found at the North American localities discussed. If other sauropod-rich regions and formations are added to this statistic (Chubut, Tendaguru, Lourinhã), this number remains constant at around $4 \%$. This low number is, along with results from allometric comparison of gastrolith mass and body mass in birds and sauropods (Wings and Sander, 2007), another argument suggesting that gastroliths were not essential for processing of foodstuffs in sauropod dinosaurs. Data on the relationship between particle size and retention time in extant animals (Clauss et al., 2009) and on scaling of gut contents (Franz et al., 2009) indicate that sauropods may have compensated for the lack of particle reduction by an increased retention time. Possible explanations for occurrence and function of the documented sauropod gastroliths include accidental or pathologic ingestion, or 
intentional ingestion for mineral uptake, especially calcium supply (Wings, 2007; Wings and Sander, 2007). In other non-avian dinosaurs, however, food processing could have been a relevant biological role for the associated gastroliths, e.g., Psittacosaurus (Osborn, 1923; You and Dodson, 2004; Sereno et al., 2010), Sinornithomimus (Kobayashi and Lü, 2003), Caudipteryx (Ji et al., 1998; Zhou and Wang, 2000), and Gasparinisaura (Cerda, 2008).

The positions of reported clast clusters within the sauropod skeletons strongly support their interpretation as former contents of the digestive tract (Wings, 2004), but, in the present absence of unique criteria to identify fossil gastroliths except via taphonomy (i.e., their association with fossil bone; Wings, 2004, 2009), transport by other mechanisms in aquatic environments (i.e., currents, vegetational rafting in tree roots, or gravitational processes; Bennett et al., 1996; Etzold and Maus, 1990; Emery, 1963) cannot completely be excluded.

Exotic clasts and wind-polished ventifacts found on the surface in Morrison outcrops are not necessarily former gastroliths. Their commonly polished surfaces (e.g., Stokes, 1987) are not a valid criterion of genuine gastroliths (Wings, 2009). It is more plausible that these clasts present weathering relicts of conglomerate beds. A plausible origin for the presence of isolated and often polished exoliths found in the sediment matrix of the Early Cretaceous Cloverly Formation has been suggested by Zaleha and Wiesemann (2005). The diamictites and wackes of the upper Cloverly Formation were deposited by hyperconcentrated flows, i.e., rivers laden with volcaniclastic sediment. Deposition could have occurred by a turbulent Newtonian flow or by progressive sedimentation from a stratified flow with a basal, incipient, granular mass flow overlain by a turbulent suspension (Zaleha and Wiesemann, 2005). Paleohydraulic calculations indicate that small pebbles could have been transported in suspension whereas larger clasts could have been transported as bedload (Zaleha and Wiesemann, 2005). Prolonged transport in ash-laden flows may also have caused the polish exhibited by many exoliths. Exoliths may just be extraformational clasts associated with hyperconcentrated flow deposits.

Gastroliths are well-documented in at least five sauropod taxa (Diplodocus, Cedarosaurus, Dinheirosaurus, Lourinhasaurus, and Barosaurus), together with weaker evidence in several other genera (e.g., Camarasaurus, Tornieria, and Dicraeosaurus). Despite their occurrence in always one individual per taxon, gastroliths were present in a diversity of taxa (diplodocoids and basal titanosauriforms). From a phylogenetic perspective, gastroliths might be expected to be more widespread among neosauropods. Careful excavation of future sauropod discoveries can be used to test that hypothesis.
Acknowledgements. This research is partially based on my doctoral thesis, and I am indebted to my supervisor P. M. Sander for his constant advice and support. D. W. Fowler is thanked for fruitful discussions and his great company in the field. W. G. Joyce helped in locating rare literature and $\mathrm{M}$. Fischer redrew some of the field maps. P. Barrett, M. Everhart, O. Rauhut, P. M. Sander, and L. Schmitz critically commented on drafts of the manuscript. I also gratefully acknowledge the comments and suggestions of the scientific editor F. Witzmann and the reviewers B. Breithaupt, D. Gillette and an anonymous referee who helped improve this paper.

I am very grateful to all the people who gave a field introduction or any other kind of advice before and during fieldwork in Argentina, Portugal, and the USA, particularly J. Bussen, K. Carpenter, D. Chure, K. Cloward, A. Elder, M. Everhart, J. Forster, M. Leschin, S. Lucas, O. Mateus, O. Rauhut, H. J. Siber, K. Stadtman, and G. Storrs. K. Cloward (Western Paleo) also provided much valuable information about the BCQ. For help during my ostrich gastrolith research which clarified many ideas about sauropod gastroliths, I wish to thank A. Olivier and R. Schumacher. Several United States federal land management agencies administer the land of the studied dinosaur sites, and I would therefore like to acknowledge the Bureau of Land Management, the National Park Service, and the National Forest Service.

The Jurassic Foundation funded my fieldwork in the USA. Additional financial support was provided by the "Graduiertenförderung Nordrhein-Westfalen", the Graduiertenkolleg "Evolution und Biodiversität in Raum und Zeit", the Volkswagen Foundation, and my family.

Edited by: F. Witzmann

Reviewed by: D. Gillette, B. Breithaupt, and one anonymous referee

\section{References}

Aberhan, M., Bussert, R., Wolf-Dieter, H., Schrank, E., Schultka, S., Sames, B., Kriwet, J., and Kapilima, S.: Palaeoecology and depositional environments of the Tendaguru Beds (Late Jurassic to Early Cretaceous, Tanzania), Mitteilungen aus dem Museum für Naturkunde Berlin, Geowissenschaftliche Reihe, 5, 19-44, 2002.

Antunes, M. T. and Mateus, O.: Dinosaurs of Portugal, C. R. Palevol., 2, 77-95, 2003.

Apesteguía, S.: Bonitasaurus salgadoi gen. et sp. nov.: a beaked sauropod from the Late Cretaceous of Patagonia, Naturwissenschaften, 91, 493-497, 2004.

Ayer, J.: The Howe Ranch Dinosaurs / Die Howe Ranch Dinosaurier, Sauriermuseum Aathal, Aathal, 96 pp., 2000.

Bakker, R. T.: The Dinosaur Heresies, Morrow, New York, 481 pp., 1986.

Behrensmeyer, A. K.: Taphonomic and ecologic information from bone weathering, Paleobiology, 4, 150-162, 1978.

Bennett, M. R., Doyle, P., and Mather, A. E.: Dropstones: their origin and significance, Palaeogeogr. Palaeocl., 121, 331-339, 1996.

Bilbey, S. A.: Cleveland-Lloyd dinosaur quarry-age, stratigraphy and depositional environments, Modern Geology, 22, 87-120, 1998. 
Bilbey, S. A.: Taphonomy of the Cleveland-Lloyd Dinosaur Quarry in the Morrison Formation, Central Utah - a lethal spring-fed pond, in: Vertebrate Paleontology in Utah, 99-1 Edn., edited by: Gillette, D. D., Miscellaneous Publication, Utah Geological Survey, Salt Lake City, 121-133, 1999.

Bird, R. T.: Bones for Barnum Brown: Adventures of a Dinosaur Hunter, Texas Christian Univ. Press, Fort Worth, 225 pp., 1985.

Bonaparte, J. F. and Mateus, O.: A new diplodocid, Dinheirosaurus lourinhanensis gen. et sp. nov., from the Late Jurassic beds of Portugal, Revista del Museo Argentino de Ciencias Naturales, 5, 13-29, 1999.

Bonaparte, J. F., Heinrich, W.-D., and Wild, R.: Review of Janenschia WILD, with the description of a new sauropod from the Tendaguru beds of Tanzania and a discussion on the systematic value of procoelous caudal vertebrae in the sauropoda, Palaeontographica Abt. A, 256, 25-76, 2000.

Breithaupt, B. H.: Como Bluff, in: Encyclopedia of Dinosaurs, edited by: Currie, P. J. and Padian, K., Academic Press, San Diego, 135-137, 1997a.

Breithaupt, B. H.: Bone Cabin Quarry, in: Encyclopedia of Dinosaurs, edited by: Currie, P. J. and Padian, K., Academic Press, San Diego, 80-81, 1997b.

Britt, B. B. and Curtice, B. D.: Dry Mesa Quarry, in: Encyclopedia of Dinosaurs, edited by: Currie, P. J. and Padian, K., Academic Press, San Diego, 196-197, 1997.

Brown, B.: Gastroliths, Science, 25, p. 392, 1907.

Calvo, J. O.: Gastroliths in sauropod dinosaurs, Gaia, 10, 205-208, 1994.

Cannon, G. L.: Sauropodan gastroliths, Science, 24, p. 116, 1906.

Carrano, M. T. and Velez-Juarbe, J.: Paleoecology of the Quarry 9 vertebrate assemblage from Como Bluff, Wyoming (Morrison Formation, Late Jurassic), Palaeogeogr. Palaeocl., 237, 147-159, 2006.

Cerda, I. A.: Gastroliths in an ornithopod dinosaur, Acta Palaeontol. Pol., 53, 351-355, 2008.

Chapman, F.: Notes on moa remains in the Mackenzie Country and other localities, Transactions and Proceedings of the New Zealand Institute, 17, 172-178, 1884.

Christiansen, P.: The evidence for and implications of gastroliths in sauropods (Dinosauria, Sauropoda), Gaia, 12, 1-7, 1996.

Chure, D. J.: Dinosaur National Monument, in: Encyclopedia of Dinosaurs, edited by: Currie, P. J. and Padian, K., Academic Press, San Diego, p. 179, 1997.

Clauss, M., Nunn, C., Fritz, J., and Hummel, J.: Evidence for a tradeoff between retention time and chewing efficiency in large mammalian herbivores, Comp. Biochem. Phys. A, 154, 376-382, 2009.

Cott, H. B.: Scientific results of an inquiry into the ecology and economic status of the Nile Crocodile (Crocodilus niloticus) in Uganda and Northern Rhodesia, Trans. Zool. Soc. Lond., 29, 211-358, 1961.

Currie, P. J.: Hovasaurus bolei, an aquatic eosuchian from the Upper Permian of Madagascar, Palaeontol. Africana, 24, 99-163, 1981.

Currie, P. J.: Gastroliths, in: Encyclopedia of Dinosaurs, edited by: Currie, P. J. and Padian, K., Academic Press, San Diego, p. 270, 1997.

Dantas, P., Freitas, C., Azevedo, T., Galopim de Carvalho, A. M., Santos, D., Ortega, F., Santos, V., Sanz, J. L., Silva, C. M. d., and Cachao, M.: Estudo dos Gastrólitos do Dinossaurio Lourinhasaurus do Jurássico Superior Português, Actas do V Congresso Nacional de Geologia, 84, A87-A89, 1998.

Darby, D. G. and Ojakangas, R. W.: Gastroliths from an Upper Cretaceous plesiosaur, J. Paleont., 54, 548-556, 1980.

Demko, T. M. and Parrish, J. T.: Paleoclimatic setting of the Upper Jurassic Morrison formation, Modern Geol., 22, 283-296, 1998.

Dodson, P., Behrensmeyer, A. K., and Bakker, R. T.: Taphonomy of the Jurassic Morrison Formation (Kimmeridgian-Portlandian) and Cloverly Formation (Aptian-Albian) of the western United States, Memoires of the Society of Geologie de France, 139, 8793, 1980a.

Dodson, P., Behrensmeyer, A. K., Bakker, R. T., and McIntosh, J. S.: Taphonomy and paleoecology of the dinosaur beds of the Jurassic Morrison Formation, Paleobiology, 6, 208-232, 1980b.

Emery, K. O.: Organic transportation of marine sediments, in: The Sea. Ideas and Observations on Progress in the Study of the Seas, edited by: Hill, M. N., Wiley Interscience, New York, 776-793, 1963.

Etzold, A. and Maus, H.: Exotische Blöcke und Gerölle im schwäbischen Lias, Jh. geol. Landesamt Baden-Württemberg, 32, 63-91, 1990.

Fiorillo, A. R.: Prey bone utilization by predatory dinosaurs, Palaeogeogr. Palaeocl., 88, 157-166, 1991.

Fiorillo, A. R.: Time resolution at Carnegie Quarry (Morrison Formation: Dinosaur National Monument, Utah): implications for dinosaur paleoecology, Contributions to Geology, University of Wyoming, 30, 149-156, 1994.

Foster, J.: Jurassic West: The Dinosaurs of the Morrison Formation and Their World, Indiana University Press, Bloomington, 2007.

Foster, J. R.: Paleoecological analysis of the vertebrate fauna of the Morrison Formation (Upper Jurassic), Rocky Mountain Region, U.S.A, Bulletin of the New Mexico Museum of Natural History \& Science, 23, 1-95, 2003.

Franz, R., Hummel, J., Kienzle, E., Kölle, P., Gunga, H.-C., and Clauss, M.: Allometry of visceral organs in living amniotes and its implications for sauropod dinosaurs, P. Roy. Soc. B-Biol. Sci., 276, 1731-1736, 2009

Gates, T. A.: The Late Jurassic Cleveland-Lloyd Dinosaur Quarry as a Drought-Induced Assemblage, PALAIOS, 20, 363-375, 2005.

Gillette, D. D.: Paleoecological significance of gastroliths in a dinosaur excavation site, Geological Society of America, Rocky Mountain Section, Abstracts with programs, 23, p. 24, 1991.

Gillette, D. D.: Form and function of gastroliths in sauropod dinosaurs, Geological Society of America, Rocky Mountain Section, 45th annual meeting, Abstracts with programs, 24, p. 14, 1992.

Gillette, D. D.: Seismosaurus, the Earth Shaker, Columbia University Press, New York, 205 pp., 1994.

Gionfriddo, J. P. and Best, L. B.: Grit use by birds - a review, Curr. Ornithol., 15, 89-148, 1999.

Hamilton, A.: Moa gizzard stones, New Zeal. J. Sci., 1, 269-270, 1891.

Heinrich, W.-D.: The taphonomy of dinosaurs from the Upper Jurassic of Tendaguru, Tanzania (East Africa), based on field sketches of the German Tendaguru expedition (1909-1913), Mitteilungen aus dem Museum für Naturkunde in Berlin, Geowissenschaftliche Reihe, 2, 25-61, 1999. 
Hill, G.: Distal alluvial fan sediments from the Upper Jurassic of Portugal: controls on their cyclicity and channel formation, J. Geol. Soc. London, 146, 539-555, 1989.

Hunt, A. P., Meyer, C. A., Lockley, M. G., and Lucas, S. G.: Archeology, toothmarks and sauropod dinosaur taphonomy, Gaia, 10, 225-231, 1994.

Janensch, W.: Ueber Magensteine bei Dinosauriern aus DeutschOstafrika, Sitzungsber. d. Ges. Naturforsch. Freunde Berlin, 1926, 34-36, 1927.

Janensch, W.: Magensteine bei Sauropoden der TendaguruSchichten, Palaeontographica, Supplement, VII, 135-144, 1929a.

Janensch, W.: Material und Formengehalt der Sauropoden in der Ausbeute der Tendaguru-Expedition, Palaeontographica, Supplement, VII, 1-34, 1929b.

Jennings, D. S. and Hasiotis, S. T.: Taphonomic analysis of a dinosaur feeding site using Geographic Information Systems (GIS), Morrison Formation, southern Bighorn Basin, Wyoming, USA, PALAIOS, 21, 480-492, 2006.

Ji, Q., Currie, P. J., Norell, M. A., and Ji, S.-A.: Two feathered dinosaurs from northeastern China, Nature, 393, 753-761, 1998.

Jukes-Browne, A. J. and Hill, W.: On the lower part of the Upper Cretaceous Series in West Suffolk and Norfolk, Quarterly Journal of the Geological Society of London, 43, 544-598, 1887.

Kobayashi, Y. and Lü, J.-C.: A new ornithomimid dinosaur with gregarious habits from the Late Cretaceous of China, Acta Palaeontol. Pol., 48, 235-259, 2003.

Lawton, R.: Taphonomy of the dinosaur quarry, Dinosaur National Monument, Contributions to Geology, University of Wyoming, 15, 119-126, 1977.

Lovelace, D. M., Hartman, S. A., and Wahl, W. R.: Morphology of a specimen of Supersaurus (Dinosauria, Sauropoda) from the Morrison Formation of Wyoming, and a re-evaluation of diplodocid phylogeny, Arquivos do Museu Nacional, 65, 527-544, 2007.

Lucas, S. G.: The gastromyths of "Seismosaurus," a Late Jurassic dinosaur from New Mexico, in: Dinosaurs of New Mexico - New Mexico Museum of Natural History and Science Bulletin, edited by: Lucas, S. G. and Heckert, A. B., 61-68, 2000.

Lucas, S. G., Spielmann, J. A., Rinehart, L. F., Heckert, A. B., Herne, M. C., Hunt, A. P., Foster, J. R., and Sullivan, R. M.: Taxonomic status of Seismosaurus hallorum, a Late Jurassic sauropod dinosaur from New Mexico, New Mexico Museum of Natural History and Science Bulletin, 36, 149-161, 2006.

Madsen, J. H.: Allosaurus fragilis: A revised osteology, Utah Geological \& Mineral Survey, Bulletin, 163 pp., 1976.

Maier, G.: Tendaguru, in: Encyclopedia of Dinosaurs, edited by: Currie, P. J. and Padian, K., Academic Press, San Diego, 725726, 1997.

Maier, G.: African Dinosaurs Unearthed: The Tendaguru Expeditions, Indiana University Press, Bloomington, 380 pp., 2003.

Manley, K.: Surface polish measurement from bona fide and suspected dinosaur gastroliths and wave and stream transported clasts, Ichnos, 2, 167-169, 1993.

Mateus, O.: Lourinhanosaurus antunesi, a new Upper Jurassic allosauroid (Dinosauria: Theropoda) from Lourinhã, Portugal, Memórias da Academia de Ciências de Lisboa, 37, 111-124, 1998.

Matthew, W. D.: Allosaurus, a carnivorous dinosaur, and its prey, American Museum Journal, 8, 2-5, 1908.
Michelis, I.: Vergleichende Taphonomie des Howe Quarry's (Morrison Formation, Oberer Jura), Bighorn County, Wyoming, USA, Institut für Paläontologie, University of Bonn, Bonn, 324 pp., 2003.

Minor, W. C.: Dinosaur gizzard stones, Rocks and Minerals, 12, 229-231, 1937.

Novas, F. E.: The Age of Dinosaurs in South America, Indiana University Press, Bloomington, 480 pp., 2009.

Osborn, H. F.: Two Lower Cretaceous dinosaurs of Mongolia, American Museum Noviates, 95, 1-10, 1923.

Paul, G. S.: Migration, in: Encyclopedia of Dinosaurs, edited by: Currie, P. J. and Padian, K., Academic Press, San Diego, 444446, 1997.

Rauhut, O. W. M., Remes, K., Fechner, R., Cladera, G., and Puerta, P.: Discovery of a short-necked sauropod dinosaur from the Late Jurassic period of Patagonia, Nature, 435, 670-672, 2005.

Remes, K.: Revision of the Tendaguru sauropod dinosaur Tornieria africana (Fraas) and its relevance for sauropod paleobiogeography, J. Vert. Paleont., 26, 651-669, 2006.

Rice, H. S. and Bierwert, T. L.: Map of the dinosaur quarry, Wyoming, AMNH Digital Special Collections, http://images. library.amnh.org/digital/items/show/24295 (last access: 2 August 2014), 1935.

Richmond, D. R. and Morris, T. H.: The dinosaur death-trap of the Cleveland-Lloyd Quarry, Emery County, Utah, Museum of Northern Arizona Bulletin, 60, 533-545, 1996.

Richmond, D. R. and Morris, T. H.: Stratigraphy and cataclysmic deposition of the Dry Mesa dinosaur quarry, Mesa County, Colorado, Modern Geol., 22, 121-143, 1998.

Sander, P. M., Christian, A., Clauss, M., Fechner, R., Gee, C. T., Griebeler, E.-M., Gunga, H.-C., Hummel, J., Mallison, H., Perry, S. F., Preuschoft, H., Rauhut, O. W. M., Remes, K., Tütken, T., Wings, O., and Witzel, U.: Biology of the sauropod dinosaurs: the evolution of gigantism, Biol. Rev., 86, 117-155, 2011.

Sanders, F., Manley, K., and Carpenter, K.: Gastroliths from the Lower Cretaceous sauropod Cedarosaurus weiskopfae, in: Mesozoic Vertebrate Life: New Research Inspired by the Paleontology of Philip J. Currie, edited by: Tanke, D. H. and Carpenter, K., Indiana University Press, Bloomington \& Indianapolis, 166-180, 2001.

Schmude, D. E. and Weege, C. J.: Stratigraphic relationship, sedimentology, and taphonomy of Meilyn: A dinosaur quarry in the basal Morrison Formation of Wyoming, Museum of Northern Arizona Bulletin, 60, 547-554, 1996.

Schwartz, H. L. and Manley, K.: Geology and stratigraphy of the Seismosaurus locality, Sandoval County; New Mexico, New Mexico Geology, 14, 25-30, 1992.

Sereno, P. C., Wilson, J. A., Witmer, L. M., Whitlock, J. A., Maga, A., Ide, O., and Rowe, T.: Structural extremes in a cretaceous dinosaur, PLoS ONE, November 2007, 1-9, 2007.

Sereno, P. C., Xijin, Z., and Lin, T.: A new psittacosaur from Inner Mongolia and the parrot-like structure and function of the psittacosaur skull, Proc. R. Soc. Lond. B, 277, 199-209, 2010.

Stokes, W. M. L.: Some field observations bearing on the origin of the Morrison "gastroliths", Science, 95, 18-19, 1942.

Stokes, W. M. L.: Dinosaur gastroliths revisited, J. Paleont., 61, 1242-1246, 1987. 
Turner, C. E. and Peterson, F.: Reconstruction of the Upper Jurassic Morrison Formation extinct ecosystem - a synthesis, Sed. Geol., 167, 309-355, 2004.

Upchurch, P. and Barrett, P. M.: The evolution of sauropod feeding mechanisms, in: Evolution of Herbivory in Terrestrial Vertebrates: Perspectives from the Fossil Record, edited by: Sues, H.-D., Cambridge University Press, Cambridge, 79-122, 2000.

Weishampel, D. B., Barrett, P. M., Coria, R. A., Le Loeuff, J., Xu, X., Zhao, X., Sahni, A., Gomani, E. M. P., and Noto, C. R.: Dinosaur distribution, in: The Dinosauria, 2nd Edn., edited by: Weishampel, D. B., Dodson, P., and Osmolska, H., University of California Press, Berkeley, 517-606, 2004.

Whittle, C. H. and Everhart, M. J.: Apparent and implied evolutionary trends in lithophagic vertebrates from New Mexico and elsewhere, New Mexico Museum of Natural History and Science Bulletin, 17, 75-82, 2000.

Wieland, G. R.: Dinosaurian gastroliths, Science, 23, 819-821, 1906.

Wings, O.: Observations on the release of gastroliths from ostrich chick carcasses in terrestrial and aquatic environments, Journal of Taphonomy, 1, 97-103, 2003.

Wings, O.: Identification, distribution, and function of gastroliths in dinosaurs and extant birds with emphasis on ostriches (Struthio camelus), Institute of Paleontology, The University of Bonn, Bonn, 187 pp., available at: http://hss.ulb.uni-bonn.de/2004/ 0462/0462.htm, URN: urn:nbn:de:hbz:5N-04626, 2004.
Wings, O.: A review of gastrolith function with implications for fossil vertebrates and a revised classification, Acta Palaeontol. Pol., 52, 1-16, 2007.

Wings, O.: A simulated bird gastric mill and its implications for fossil gastrolith authenticity, Fossil Record, 12, 91-97, 2009.

Wings, O. and Sander, P. M.: No gastric mill in sauropod dinosaurs: new evidence from analysis of gastrolith mass and function in ostriches, P. Roy. Soc. B: Biol. Sci., 274, 635-640, 2007.

You, H.-L. and Dodson, P.: Basal Ceratopsia, in: The Dinosauria, 2nd edition ed., edited by: Weishampel, D. B., Dodson, P., and Osmolska, H., University of California Press, Berkeley, 478-493, 2004.

Zaleha, M. J. and Wiesemann, S. A.: Hyperconcentrated flows and gastroliths: sedimentology of diamictites and wackes of the upper Cloverly Formation, Lower Cretaceous, Wyoming, U.S.A., J. Sediment. Res., 75, 43-54, 2005.

Zhou, Z.-H. and Wang, X.-L.: A new species of Caudipteryx from the Yixian Formation of Liaoning, northeast China, Vertebrat. PalAsiatic., 38, 111-127, 2000. 